University of Nebraska - Lincoln

DigitalCommons@University of Nebraska - Lincoln

H. W. Manter Laboratory Library Materials

$9-1914$

Dr. Nott's Theory of Insect Causation of Disease

William A. Riley

Cornell University

Follow this and additional works at: https://digitalcommons.unl.edu/manterlibrary

Part of the Environmental Public Health Commons, Other Animal Sciences Commons, Parasitic

Diseases Commons, Parasitology Commons, and the Zoology Commons

Riley, William A., "Dr. Nott's Theory of Insect Causation of Disease" (1914). H. W. Manter Laboratory Library Materials. 6.

https://digitalcommons.unl.edu/manterlibrary/6

This Article is brought to you for free and open access by DigitalCommons@University of Nebraska - Lincoln. It has been accepted for inclusion in H. W. Manter Laboratory Library Materials by an authorized administrator of DigitalCommons@University of Nebraska - Lincoln. 


\title{
DR. NOTT'S THEORY OF INSECT CAUSATION OF DISEASE
}

\author{
William A. Riley \\ Cornell University.
}

The danger in using isolated sentences from an article as a basis for interpreting the author's theories, is generally recognized, but sometimes the most careful workers fall into the trap. Once the mistaken interpretation is published, it may be copied over and over again until it rises to the dignity of a dogma.

A striking illustration is afforded by the practical unanimity with which writers on the subject of insects and disease credit Dr. Josiah Nott with being the earliest to formulate definitely the theory of mosquito transmission of yellow fever.

Nuttall, in his classic monograph "On the Rôle of Insects, Arachnids and Myriapods as Carriers in the Spread of Bacterial and Parasitic Diseases" (1899), states: "In 1848, Nott of New Orleans published an essay on yellow fever, in which he refers to malaria as if the mosquito theory had already been advanced, and he gives grounds for his belief that the mosquito also gives rise to yellow fever."

The original publication was not accessible to Dr. Nuttall, who was forced to depend on an abstract furnished by Dr. Isadore Dyer of New Orleans. Following Nuttall, almost every writer on the historical aspect of the theory of insect transmission of disease, especially yellow fever, refers to Nott's theory, and some who have evidently seen and hurriedly read the original, quote specific statements which seem to indicate clearly the intent of the argument.

Dr Nott's scholarly paper on "The Cause of Yellow Fever" was published in the New Orleans Medical and Surgical Journal, vol. iv, in March, 1848. A cursory reading of it, in the light of present-day knowledge, affords ample indication that he believed in the insect transmission not only of yellow fever, but also of malaria and various other diseases. For instance, one could hardly draw any other conclusion from reading such isolated statements as:

"The morbific cause of yellow fever is not amenable to any of the laws of gases, vapors, emanations, etc., but has an inherent power of propagation, independent of the motions of the atmosphere, and which accords in many respects with the peculiar habits and instincts of insects.

"There are even perfectly authenticated instances where one side or end of a ship has suffered severely from the disease while the other was entirely free from it. We can readily believe that certain insects which are endowed with unaccountable instincts and habits, might attack a part of a ship, of a 
tree, of a wheat or cotton field, but we cannot imagine how a gas could be turned loose on one side of the cabin of a vessel and not extend to the other.

"It would certainly be quite as philosophic (as the malarial theory) to suppose that some insect or animalcule hatched in the lowlands, like the mosquito, after passing through its metamorphosis takes flight and either from a preference for a different atmosphere, or impelled by one of those extraordinary instincts which many are known to possess, wings its way to the hill top to fulfil its appointed destiny."

Explicit as these statements seem, they can be interpreted only when we remember that Nott wrote at a period before Pasteur and Koch had completely revolutionized the ideas of medical men regarding the causation of disease, and that he was in reality presenting a masterly argument in favor of a germ theory of disease. No one can read the entire article, in its proper historical setting, without realizing that Dr. Nott used the term "insect" to denominate micro-organisms, and that his explicit references to true insects were merely for the purpose of illustrating the propagation, methods of development and habits of the invisible "insects" or "animalcules" whose existence he postulated.

He did speak of "the perfect analogy between the habits of certain insects and yellow fever," but he had no more intention of urging that the disease was mosquito borne than that it was carried by the aphids, Hessian flies or cotton worms that he also cites for illustration.

If, after reading the full article, additional evidence is desired, it is furnished in a conclusive manner by going still further back. Dr. Nott takes pains to explain that "there is no novelty in the doctrine of the insect or animalcule origin of disease" and states that "the most elaborate and ingenious article I have met with is that in Sir Henry Holland's Medical Notes, "On the Hypothesis of Insect Life as a Cause of Disease."

On referring to that interesting book, printed in 1839 , we find that Dr. Holland raises the question as to "what weight we may attach to the opinion that certain diseases, and especially some of epidemic and contagious kind, are derived from minute forms of animal life, existing in the atmosphere under particular circumstances."

His use of the term "insect" is illustrated by the statement:

"It is only of late that the wonderful eye of the microscope has clearly disclosed to us that vast domain of life to which the infusoria belong; a new world which might have remained forever as much hidden from our sense and knowledge as the invisible forms of insect life, of which the hypothesis before us presumes the existence.

"If existing, the same analogy will lead us to other inferences, not less probable, as to those habits and instincts, in which they may be presumed to have affinity for the known insect genera. Such are their frequent sudden generation, at irregular and often distant periods, under certain circumstances of season or locality, or under other conditions, less obvious to apprehension. Secondly, the diffusion of swarms, so generated, and with rapidly repeated 
propagation, over wide tracts of country, and often following particular lines of movement. To which general inferences may be added another (resting on analogy, though of less explicit kind), namely, that certain of these animalcule species may act as poisons, or causes of disease.

"Whatever is true as to the habits of insects obvious to our senses, is likely to be more especially so in those whose minuteness removes them further from observation." (Italics mine.)

It was to the support of this hypothesis of causation of disease by micro-organisms and this alone, that Nott brought a wealth of observations on yellow fever and malaria, and he deserves full credit for the logical manner in which he analyzed and presented his data. 